\title{
Women in the
}

American Welfare Trap 
This page intentionally left blank 


\section{Women in the \\ American Welfare Trap}

Catherine Pélissier Kingfisher

$\overline{\text { PENN }}$

University of Pennsylvania Press

Philadelphia 
Copyright $(\mathcal{O} 1996$ by Catherine Pélissier Kingfisher

All rights reserved

Printed in the United States of America

Library of Congress Cataloging-in-Publication Data

Kingfisher, Catherine Pélissier.

Women in the American welfare trap / Catherine Pélissier Kingfisher.

p. $\mathrm{cm}$.

Includes bibliographical references and index.

ISBN 0-8122-3287-9 (cloth : alk. paper). - ISBN 0-8122-1515-X (pbk : alk. paper)

1. Poor women-United States. 2. Welfare recipients-United States. 3. Human services personnel-United States. 4. Public welfare-United States. 5. Aid to families with dependent children programs-United States. 6. Welfare rights movement-United States. I. Title.

HVI 445.K57 1996

$362.83^{\prime} 8^{\prime} 093-\mathrm{dc} 20$

96-19862

CIP 
Language is also a place of struggle.

bell hooks

Politics is, essentially, a matter of words.

Pierre Bourdieu 
This page intentionally left blank 